\title{
Penerapan Pendekatan Scientific Untuk Mengukur Hasil Belajar Fisika Siswa Kelas X SMA Negeri 1 Parigi
}

\author{
Fitriana, Syamsu dan Amiruddin Hatibe \\ e-mail: Fitriana.fisika@yahoo.com \\ Program Studi Pendidikan Fisika FKIP Universitas Tadulako \\ Jl. Soekarno Hatta Km. 9 Kampus Bumi Tadulako Tondo Palu - Sulawesi Tengah
}

Penelitian ini bertujuan untuk mengetahui perbedaan hasil belajar fisika antara siswa yang mengikuti pendekatan pembelajaran scientific dengan siswa yang mengikuti pendekatan pembelajaran konvensional di kelas X SMA Negeri 1 Parigi. Jenis penelitian yang digunakan adalah eksperimen kuasi dengan desain posttest pretest only control group design.Populasi penelitian ini adalah seluruh siswa kelas X SMA Negeri 1 Parigi. Teknik pengambilan sampel adalah purposive sampling. Kelas X A sebagai kelas eksperimen dan kelas X B sebagai kelas kontrol. Instrumen tes hasil belajar berupa tes pilihan ganda yang telah divalidasi. Hasil perhitungan statistik dari uji perbandingan hasil belajar fisika menggunakan uji-t didapatkan harga $t_{\text {hitung }}>t_{\text {tabel }}$ dengan nilai $t_{\text {hitung }} 3,33$ dan $t_{\text {tabel }}$ pada taraf signifikansi $5 \%$ dan $\mathrm{dk}=58$ adalah 2,00. Disimpulkan bahwa ada perbedaan hasil belajar fisika antara siswa yang mengikuti pendekatan pembelajaran scientific dengan siswa yang mengikuti pendekatan pembelajaran konvensional di kelas X SMA Negeri 1 Parigi.

Kata Kunci : Pendekatan pembelajaran scientifc, Hasil belajar fisika.

\section{PENDAHULUAN}

Dewasa ini, telah diberlakukannya kurikulum baru oleh dinas pendidikan republik Indonesia yaitu kurikulum 2013. Kurikulum adalah seperangkat rencana dan pengaturan mengenai tujuan, isi, dan bahan pelajaran serta cara yang digunakan sebagai pedoman penyelenggaran kegiatan pembelajaran untuk mencapai tujuan pendidikan pendidikan tertentu (UU nomor 20 tahun 2003). Kurikulum 2013 merupakan sebuah kurikulum berbasis kompetensi yang diarahkan pada pencapaian kompetensi yang dirumuskan dalam SKL (Standar Kompetensi Lulusan). Kurikulum 2013 mengunakan sebuah konsep pendekatan ilmiah (scientific). Dalam pendekatan ilmiah pembelajaran yang dilakukan berbasis pada fakta yang dapat dijelaskan dengan logika. Sehingga siswa mampu menemukan sebuah jawaban yang tidak berdasarkan angan-angan atau pendapat tidak masuk akal tetapi melalui proses ilmiah yang struktural.

Proses pembelajaran dengan menggunakaan pendekatan scientific jauh berbeda dengan pembelajaran konvensional di mana guru merupakan sumber informasi siswa dan guru selalu aktif menjelaskan, menuntun siswa hingga siswa mengerti. Dengan cara ini waktu yang dibutuhkan dalam proses siswa dari tidak mengerti menjadi paham membutuhkan waktu yang lama, sehingga kurang efisien. Dalam pendekatan ilmiah masalah yang diberikan guru selalu berdasarkan dengan fenomena yang selama ini terjadi di kehidupan para siswa, lalu siswa mencoba mencari jawaban dari masalah yang diberikan secara mandiri. Pendekatan ilmiah (scientific approach) dalam pembelajaran sebagaimana dimaksud meliputi mengamati, menanya, mencoba, mengolah, menyajikan dan menciptakan jejaring. Sehingga siswa tidak hanya mengetahui fakta atau prinsip, tetapi harus terampil menerapkan pengetahuannya dalam kehidupan.

Mata pelajaran Fisika merupakan salah satu mata pelajaran dalam rumpun sains yang mempelajari gejala-gejala alam. Untuk memahami gejala-gejala alam tersebut, peserta didik membutuhkan kemampuan berpikir analitis induktif dan deduktif. Pengembangan kemampuan analitis yang dibutuhkan dalam mempelajari Fisika dapat dilakukan dengan melatih peserta didik untuk memahami konsepkonsep fisis dari pengalaman langsung. Dalam hal ini, pendekatan scientific menjadi pilihan yang patut untuk dipertimbangkan.

Unsur-unsur penting sebuah pendekatan pembelajaran merupakan sebuah landasan dan sudut pandang terhadap proses pembelajaran, memuat serangkaian kegiatan untuk mencapai sebuah tujuan tertentu dan merupakan jalan 
yang ditempuh untuk menyampaikan materi pembelajaran. Dalam proses pembelajaran berbasis pendekatan ilmiah menyentuh tiga ranah yaitu ranah sikap, pengetahuan dan ketrampilan. Ranah sikap mengamit transformasi materi ajar agar peserta didik "tahu mengapa", ranah pengetahuan mengamit transformasi materi agar seorang peserta didik "tahu bagaimana", dan ranah ketrampilan mengamit transformasi materi agar siswa didik "tahu apa". Sebagai hasil akhhirnya seorang peserta didik mampu menyeimbangkan kemampuan soft skill dan hard skillnya sehingga menjadi manusia yang memiliki kecakapan untuk meningkatkan kualitas hidup mereka.

Kurikulum 2013 menerapkan proses pembelajaran dengan pendekatan saintifk yang terdiri atas lima pembelajaran pokok yaitu: (1) mengamati(observes);(2)menanya (questions); (3)mengumpulkaninformasi(experiments/explor es);(4)mengasosiasi(analyzes);(5)mengkomuni kasikan (communicates).

Setelah mengadakan observasi di SMA Negeri 1 Parigi, peneliti mendapatkan informasi bahwa hasil belajar Fisika peserta didik di sekolah ini berada pada tingkatan yang cukup baik. Hal ini tentu saja merupakan hasil dari kerja keras guru sebagai pemeran utama dalam proses pembelajaran. Namun, seperti yang kita ketahui bahwa pendidikan harus tetap berkembang dan berinovasi untuk meningkatkan mutunya. Sehingga saat ini guru tidak lagi menjadi pemeran utama dalam proses pembelajaran, karena peran tersebut telah menjadi milik peserta didik. Dan hasilnya adalah, masih banyak peserta didik yang bahkan tidak tertarik dengan mata pelajaran fisika dan menyebabkan hasil belajar fisika mereka tidak memenuhi standar minimal yang telah ditetapkan. Mengapa? Apakah guru? Apakah isi materi? Atau apakah proses pembelajaran?

Dapat di simpulkan bahwa proses pembelajaran mencakup semua hal yang memungkinkan untuk memengaruhi hasil belajar fisika peserta didik. Sehingga langkahlangkah yang digunakan dalam proses pembelajaran merupakan hal yang sangat penting pada penelitian ini dalam rangka membantu peserta didik mencapai hasil belajar yang maksimal. Kondisi peserta didik di sekolah ini yang sangat antusias terhadap hal-hal baru, membuat peneliti berharap dapat menciptakan kondisi ideal yang dibutuhkan untuk melaksanakan penelitian eksperimen ini secara maksimal.

Fauziah (2013) Pada RPP berbasis pendekatan saintifik melalui model pembelajaran PBL berhasil memotivasi dan menanamkan sikap internal pada peserta didik. Tahap-tahap pendekatan saintifik dapat meningkatkan kemampuan peserta didik dalam mengamati, menanya, menalar, mencoba dan mengkomunikasikan temuannya, sehingga berdampak positif terhadap kemampuan soft skill-nya. Penilaian berbasis portofolio dirasakan lebih objektif dan otentik menilai kinerja peserta didik.[5]

Atsnan (2013) Suatu pendekatan berpikir dan berbuat yang diawali dengan mengamati dan menanya sampai kemudian mereka berupaya untuk mencoba, mengolah, menyaji, menalar, dan akhirnya mencipta. Itulah mengapa pendekatan scientific ini akan bermuara kepada tingkatan mencipta (to create) yang tentunya terdapat unsur kreativitas di dalamya.[2]

Mulyono (2012) Analisis kebutuhan perangkat pembelajaran, di SMA 1 Kandangserang masih berpusat pada guru dengan metode ceramah. Dalam penelitian ini dikembangkan perangkat pembelajaran biologi dengan pendekatan scientific skills teknologi fermentasi berbasis masalah lingkungan pada limbah produksi tempe-tahu. Pengembangan perangkat pembelajaran dengan menambahkan beberapa indikator, berpusat pada peserta didik.[9]

Dalam penelitian Yatin Mulyono (2012) melalui pendekatan scientific peserta didik dituntut untuk mampu merancang langkahlangkah kerja sendiri serta melaporkan hasil praktikum baik berupa laporan maupun presentasi. sendiri serta melaporkan hasil praktikum baik berupa laporan maupun presentasi. Menurut Lavoie (dalam Yatin, 2012) pembelajaran dengan pendekatan scientific skill memiliki keuntungan yang signifikan dibandingkan dengan model pembelajaran pendekatan tradisional. Penjabaran scientific skill yang dimaksud adalah (1) kemampuan membuat rancangan percobaan; kemampuan melakukan percobaan dan melaporkan hasilnya; (3) pengusaaan konsep proses sains yang baik; dan (4) kemampuan mempresentasikan hasil percobaan dengan baik.[15]

Rumusan masalah dari penelitian ini adalah "Apakah terdapat perbedaan hasil belajar fisika antara siswa yang mengikuti 
pendekatan pembelajaran scientific dengan siswa yang mengikuti pendekatan pembelajaran konvensional di kelas X SMA Negeri 1 Parigi?

\section{METODE PENELITIAN}

Jenis penelitian ini merupakan penelitan quasi eksperimen atau quasi experimental design (eksperimen semu).

Desain penelitian eksperimen ini menggunakan posttest pretest only control group design. Desain penelitian yang digunakan dapat dilukiskan seperti pada Tabel 1 .

Tabel 1: Posttest-pretest only experiementel design

\begin{tabular}{lccc} 
Kelompok & Pre-test & treatmen & Post-test \\
\hline $\begin{array}{l}\text { Eksperimen } \\
\text { Kontrol }\end{array}$ & $\mathrm{O}$ & $\mathrm{X}$ & $\mathrm{O}$ \\
& $\mathrm{O}$ & - & $\mathrm{O}$ \\
\hline
\end{tabular}

Keterangan:

X
: perlakuan denga penbelajaran scientific
pemberatan
O Tes hasil belajar
Penelitian dilakukan di SMA Negeri 1 Parigi. Penelitian dilaksanakan pada bulan Agustus-Oktober 2015. Populasi dalam penelitian ini adalah seluruh siswa kelas X SMA Negeri 1 Parigi tahun pelajaran 2015/2016 yang terdiri dari 3 kelas. Sampel dalam penelitian ini adalah kelas X A dan X B. Teknik pengumpulan sampel yang digunakan adalah purposive sampling, yaitu teknik penentuan sampel dengan pertimbangan tertentu.

Instrumen yang digunakan dalam penelitian adalah tes hasil belajar fisika. Tes tersebut digunakan untuk mengetahui perbedaan metode yang diterapkan pada kelas yang menjadi sampel penelitian. Tes dibuat dalam bentuk pilihan ganda sebanyak 30 item soal. Proses analisis tes dilakukan sebanyak dua kali. Yang pertama, validitas ahli yang ditekankan pada validitas isi dan validitas konstruksi. Yang kedua, adalah uji coba tes, kemudian dilanjutkan dengan menganalisis berdasarkan validitas item, tingkat kesukaran, daya pembeda, dan reliabilitas tes.

Berdasarkan hasil validitas ahli dan uji coba tes, dari 30 item soal yang diuji cobakan pada kelas X SMA 1 Parigi Tengah, tidak semua soal dianggap memenuhi syarat (valid). 5 soal yang tidak valid, sehingga soal yang digunakan sebagai tes hasil belajar fisika totalnya berjumlah 25 soal.

Teknik analisis data dalam penelitian ini terlebih dulu dilakukan uji normalitas untuk mengetahui apakah data yang diperoleh berdistribusi normal atau tidak. Uji normalitas yang digunakan yaitu uji chi kuadrat. Sedangkan Pengujian hipotesis yang digunakan adalah uji t (uji dua pihak). Jenis uji statistika ini bertujuan untuk membandingkan rata-rata dua grup yang saling berpasangan.

\section{HASIL DAN PEMBAHASAN}

1. Hasil Penelitian

A. Uji Normalitas

Pengujian data normalitas data penelitian ini peneliti menggunakan Chi-kuadrat dengan kriteria penerimaan $x^{2}$ hitung $<X^{2}$ tabel, taraf signifikan $\alpha=0,05$, dan derajat kebebasan $\mathrm{dk}=\mathrm{k}-3$. Data yang digunakan untuk menguji normalitas data meliputi tes awal dan tes hasil belajar baik kelas eksperimen maupun kelas kontrol. Hasil uji normalitas tes awal dan tes akhir dari kelas eksperimen dan kelas kontrol dapat dilihat pada Tabel 2 .

Tabel 2 : Hasil Uji Normalitas Tes Awal dan Tes Akhir Kelas Eksperimen dan Kelas Kontrol

\begin{tabular}{|lcccc}
\hline \multirow{2}{*}{ Uraian } & Tes Awal & \multicolumn{3}{c}{ Tes Akhir } \\
\cline { 2 - 5 } & Eksperimen & Kontrol & Eksperimen & Kontrol \\
\hline Sampel & 30 & 30 & 30 & 30 \\
$x_{\text {Hitung }}^{2}$ & 2,89 & 1,90 & 3,39 & 2,47 \\
$x_{\text {tabel }}^{2}$ & \multicolumn{2}{c}{7,81} & \multicolumn{3}{c}{7,81} & \\
Ket & \multicolumn{2}{c}{ Normal } & \multicolumn{3}{c}{ Normal } \\
\hline
\end{tabular}

Berdasarkan uji normalitas pada Tabel 2 dengan menggunakan Chi-kuadrat dengan

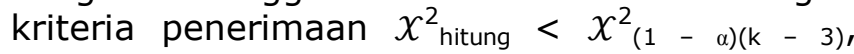
dimana untuk tes awal baik kelas eksperimen maupun kelas kontrol nilai $X^{2}$ hitung lebih kecil daripada nilai $x^{2}{ }_{(1-\alpha)(k-3)}$. Begitupula untuk tes

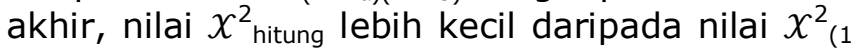
$-\alpha)(k-3)$, baik di kelas eksperimen maupun kelas kontrol. Artinya, data tes awal dan tes akhir baik di kelas eksperimen maupun kelas kontrol terdistribusi normal.

\section{B. Uji Homogenitas \\ Pengujian}

data homogenitas menggunakan uji-F dengan kriteria jika $F_{\text {hitung }}<$

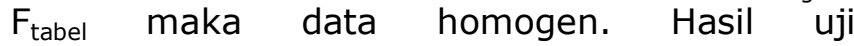
homogenitas dari kelas eksperimen dan kelas kontrol dapat dilihat pada Tabel 3.

Tabel 3. Hasil Uji Homogenitas Tes Awal dan Tes Akhir

\begin{tabular}{lccc}
\hline Uraian & Tes awal & Tes Akhir & Ket \\
\hline$F_{\text {hitung }}$ & 0,72 & 1,00 & \\
& & & Homogen \\
$\mathrm{F}_{\text {tabel }}$ & 1,77 & 1,77 & \\
\hline
\end{tabular}


Berdasarkan Tabel 3, nilai $\mathrm{F}_{\text {hitung }}<\mathrm{F}_{\text {tabel }}$. Hal ini menunjukkan bahwa data tersebut memiliki varians yang sama (homogen).

\section{Uji Hipotesis}

Uji Perbedaan Rata-Rata

Pengujian hipotesis ini menggunakan uji dua pihak. Data hasil tes awal dan tes akhir dapat dilihat pada Tabel 4 dan Tabel 5.

Tabel 4 : Uji Perbedaan Rata - Rata Kelas Eksperimen dan Kelas Kontrol

\begin{tabular}{|c|c|c|c|}
\hline Kelas & $\overline{\mathbf{X}}$ & $t_{\text {bitung }}$ & $t_{\text {tabel }}(\alpha=0,05)$ Keputusan \\
\hline Eksperimen & 5,97 & & \\
\hline Kontrol & 5,03 & 0,20 & $\mathrm{H}_{0}$ diterima \\
\hline
\end{tabular}

Berdasarkan Tabel 4 Nilai $t_{\text {hitung }}>t_{\text {tabel }}$ atau $3,33>1,70$. Hal ini menunjukkan bahwa thitung berada diluar daerah penerimaan $\mathrm{H}_{\mathrm{o}}$. Dengan demikian dapat disimpulkan bahwa terdapat perbedaan rata-rata ha antara siswa yanil belajar mendapatkan pendekatan pembelajaran scientific lebih tinggi dari pendekatan pembelajaran konvensional.

\section{Pembahasan}

Pendekatan scientific atau pendekatan ilmiah merupakan suatu cara atau mekanisme pembelajaran untuk memfasilitasi siswa agar mendapatkan pengetahuan atau keterampilan dengan prosedur yang didasarkan pada suatu metode ilmiah. Pendekatan scientific atau pendekatan ilmiah memerlukan langkahlangkah pokok yaitu observing (mengamati), questioning (menanya), associating (menalar), experimenting (mencoba), dan networking (membentuk jejaring), (Kemendikbud, 2013).[7] Siswa belajar bersama teman kelompoknya, mengemukakan ide-ide ataupun jawaban-jawaban yang berbeda dan benar untuk menyelesaikan pertanyaan-pertanyaan dalam LKK. Pada tahap ini siswa terlatih untuk menerima perbedaan pendapat dan berusaha untuk bekerjasama. Selain itu juga membantu siswa belajar mengembangkan pemikirannya, memberikan kesempatan kepada siswa untuk berperan aktif dalam proses pembelajara.

Penelitian ini bertujuan untuk mengetahui bagaimana studi komparasi pendekatan pembelajaran Scientific dengan pendekatan pembelajaran konvensional terhadap hasil belajar fisika siswa. Maksudnya, peneliti melakukan penelitian dengan menggunakan pendekatan Scientific. Perlakuan ini dilakukan untuk melihat bagaimana hasil belajar siswa, apakah berubah ke konsep fisika yang sebenarnya atau tidak setelah diberikan perlakuan. Setelah itu dilihat bagaimana akibat dari pendekatanj yang digunakan tersebut terhadap hasil belajarnya, apakah meningkat atau tidak.

Ada dua sampel yang digunakan pada penelitian ini yaitu kelas eksperimen dan kelas kontrol. Untuk kelas kontrol pendekatan pembelajaran yang digunakan adalah konvensional, sedangkan kelas eksperimen diberikan pendekatan pembelajaran Scientific. Scientific merupakan salah satu alternatif yang dapat meningkatkan hasil belajar siswa sekaligus hasil belajar fisika siswa.

Pada kelas eksperimen siswa menjadi lebih banyak aktif dalam pembelajaran, bekerja sama baik secara perorangan maupun kelompok, mandiri, dan bertanggung jawab atas ketuntasan bagian materi pelajaran yang harus dipelajari serta menyampaikan materi tersebut kepada anggota kelompok lain. Sehingga wawasan daya berpikir siswa mulai berkembang dan menyadari begitu banyak halhal atau kejadian yang mereka lakukan seharihari banyak yang berkaitan dengan materi fisika, contoh yang berkaitan dengan materi ini adalah pengukuran. Berbicara tentang pengukuran dalam kehidupan kita sudah tidak asing lagi karena hal ini sering bahkan setiap hari kita lakukan seperti menimbang, mengukur pipa misalnya.

Sesuai dari hasil yang diperoleh peneliti dalam proses pembelajaran, siswa yang ada dikelas eksperimen pada pertemuan awal semangat untuk mengikuti pelajaran sedikit berkurang. Akan tetapi sebelum peneliti masuk dalam proses pembelajaran, maka diawali dengan memotivasi siswa dengan memberi sebuah pertanyaan yang berkaitan dengan materi yang akan diajarkan tersebut.

Contohnya, "Berapakah panjang jarak antara dua gores panjang yang berdekatan? Berapakah panjang jarak antara dua gores pendek yang berdekatan?", maka disini mulailah perdebatan antara siswa sehingga dari hal tersebut menjadikan mereka penasaran dengan jawaban yang sebenarnya. Peneliti tidak langsung memberi jawaban yang benar kepada siswa melainkan melanjutkan dengan memberikan materi tentang pengukuran, supaya bisa mengetahui materi yang diperlukan untuk menyelesaikan masalah yang diajukan tersebut. Setelah siswa belajar materi pengukuran, siswa mulai memiliki pengetahuan yang baru, dimana pada tahap awal mereka belum mengetahui "Berapakah panjang jarak antara dua gores yang 
berdekatan? dan " Dapatkah anda mengukur diameter kelereng secara teliti dengan menggunakan mistar?". Pertanyaan tersebut membuat mereka menjadi penasaran dan menimbulkan rasa keingin tahuan akan jawaban tersebut, sehingga siswa memiliki semangat dan motivasi untuk mau belajar akan materi tersebut. Setelah siswa belajar materi pengukuran, dalam hal ini siswa diberi penjelasan dengan disertai demonstrasi yang singkat kemudian masuk dalam proses perlakuan, siswa mulai mengerti akan pertanyaan yang diberikan pada tahap awal tersebut. Maka peneliti kembali menanyakan tentang pertanyaan awal yang menghadirkan perdebatan dan secara langsung siswa menjawab pertanyaan sesuai dengan materi yang diajarkan.

Dari tahap-tahap yang telah dilakukan dalam proses belajar, siswa dilatih untuk bisa aktif selama kegiatan pembelajaran berlangsung, aktif dalam melakukan kegiatan, aktif berpikir, dan memberikan makna tentang hal-hal yang dipelajari. Dari pembelajaran tersebut siswa juga diharapkan untuk bisa menemukan sendiri solusi dari masalahmasalah yang diajukan, sedangkan peneliti hanya membantu agar proses pembelajaran Scientific dapat berlangsung lancar. Dalam pembelajaran ini, siswa diajar untuk bisa menemukan masalah-masalah yang diberikan bahkan siswa dilatih untuk membentuk pengetahuannya sendiri. Sesuai dengan pembelajaran yang mengharapkan siswa bisa berperan aktif dalam kegiatan belajar agar dapat memperoleh hasil belajar yang baik.

Berbeda dengan pembelajaran yang diterapkan pada kelas kontrol adalah pembelajarn konvensional, dimana dalam proses pembelajarannya pada tahap awal siswa langsung diberi materi kemudian diberikan ceramah. Maka suasana dalam kegiatan belajar terlihat vakum dan siswa kurang aktif terlibat dalam proses pembelajaran. Bahkan siswa yang memiliki tempat duduk yang dibelakang tidak menanggapi pelajaran yang sedang berlangsung, justru mereka hanya melakukan diskusi yang tidak berkaitan dengan pembelajaran.

Berdasarkan hasil analisis kualitatif pemberian tes awal (pretest) yang sesuai pada tabel 4.1 diperoleh skor rata-rata dari masingmasing kelas adalah 5,97 dengan standar deviasi adalah 3,16 untuk kelas eksperimen dan 5,03 dengan standar deviasinya adalah 2,53 untuk kelas kontrol. Hasil ini menunjukkan adanya perbedaan skor antara kedua kelas, dimana terlihat skor untuk kelas eksperimen lebih tinggi dibandingkan kelas kontrol. Selanjutnya, untuk kemampuan siswa dari pemberian tes akhir (posttest) diperoleh nilai rata-rata dari masing-masing kelas adalah 16,03 dengan standar deviasinya adalah 6,81 untuk kelas eksperimen dan 9,90 dengan standar deviasinya adalah 2,40 untuk kelas kontrol.

Berdasarkan data yang diperoleh tersebut, kemudian dilakukan analisis terhadap uji normalitas serta uji homogenitas varians. Hasilnya baik data tes awal maupun tes akhir keduanya berdistribusi normal, yang berdasrkan pada tabel 4.2 dan tabel 4.3 dengan menggunakan Chi-kuadrat dengan kriteria penerimaan $\chi^{2}$ hitung $<\chi^{2}$ tabel, dimana untuk tes awal baik kelas eksperimen maupun kelas kontrol nilai $\chi^{2}$ hitung lebih kecil daripada nilai $\chi^{2}$ tabel. Dimana nilai $\chi^{2}$ hitung untuk kelas eksperimen adalah $2,88<7,81$ dan untuk kelas kontrol 1,91<7,81. Sesuai kriteria pengambilan keputusan, maka baik data dari kelas eksperimen maupun kelas kontrol keduanya berasal dari populasi yang terdiribusi normal. Pada tes akhir kelas eksperimen maupun kelas kontrol nilai $\chi^{2}$ hitung lebih kecil

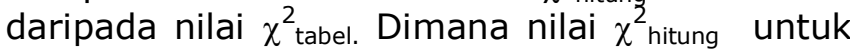
kelas eksperimen adalah 3,39<7,81 dan untuk kelas kontrol $2,47<7,81$. Sesuai kriteria pengambilan keputusan, maka baik data dari kelas eksperimen maupun kelas kontrol keduanya berasal dari populasi yang terdistribusi normal, serta memiliki varians yang homogen dapat dilihat berdasarkan pada tabel 4.4 dan tabel 4.5 dimana nilai $F_{\text {hitung }}<$ $\mathrm{F}_{\text {tabel. }}$. Hal ini menunjukkan bahwa data tersebut memiliki varians yang sama (homogen).

Berdasarkan analisis kuantitatif data tes akhir diketahui, nilai rata-rata kelas eksperimen lebih besar dibandingkan dengan nilai rata-rata kelas kontrol. Perbedaan antara rerata skor tes akhir kelas eksperimen dan kelas kontrol menunjukkan adanya perbedaan pada pembelajaran yang diterapkan pada kedua kelas tersebut. Perbedaan yang signifikan terjadi pada kelas eksperimen. Dimana kelas eksperimen menggunakan pendekatan pembelajaran scientific sedangkan kelas kontrol menggunakan pendekatan pembelajaran konvensional.

Selanjutnya dengan menggunakan rata-rata skor dapat dilihat hasil uji hipotesis tes awal dan tes akhir dapat dilihat sesuai tabel 4.6 dan tabel 4.7 dimana pada masing-masing 
kelas telah diberi perlakuan, diperoleh nilai $t_{\text {hitung }}=0,20$ untuk tes awal dan nilai $t_{\text {hitung }}=$ 3,33 untuk tes akhir dan nilai $t_{\text {tabel }}=2,00$. Dengan menggunakan kriteria penerimaan $\mathrm{H}_{0}$ dimana $-\mathrm{t}_{(1-0,5 \mathrm{a})}<\mathrm{t}<\mathrm{t}_{(1-0,5 \mathrm{a})}$, diketahui hipotesis $\mathrm{H}_{0}$ tidak terpenuhi atau ditolak dan hipotesis satu $\left(\mathrm{H}_{1}\right)$ diterima. Sehingga pada tes akhir diperoleh $\mathrm{H}_{1}$ (diterima) Artinya terdapat perbedaan hasil belajar fisika antara siswa yang diajarkan dengan menggunakan pendekatan pembelajaran scientific dan siswa yang diajarkan dengan menggunakan pendekatan pembelajaran konvensional.

\section{KESIMPULAN}

Berdasarkan penelitian dan analisis data dapat disimpulkan, bahwa pendekatan pembelajaran scientific yang digunakan memberikan dampak positif terhadap hasil belajar siswa. Hal ini dapat dilihat berdasarkan hasil posttest skor rata-rata hasil belajar siswa kelas kontrol sebesar 10,63 dengan standar deviasinya adalah 2,82 dan skor rata-rata kelas eksperimen sebesar 15,96 dengan standar deviasinya adalah 2,78 dari skor maksimum 25. Terdapat perbedaan hasil belajar fisika antara siswa yang mengikuti pendekatan pembelajaran scientific dengan siswa yang mengikuti pendekatan pembelajaran konvensional di kelas $X$ SMA Negeri 1 Parigi.

\section{DAFTAR PUSTAKA}

[1] Arikunto. S, 2007 : 100). Active Learning. Kencana Prenada Media Group:Jakarta.

[2] Atsnan, M. F dan Gazali Y. R. (2013). Penerapan Pendekatan Scientific dalam Pembelajaran Matematika SMP Kelas VII Materi Bilangan (Pecahan). Yogyakarta : Pendidikan Matematika Pasca Sarjana UNY.(Online),(http://eprints.uny.ac.id/10777/1/P\%20 -\%2054.pdf, diakses 14 Februari 2013).

[3] Anang Megocahyo Wijipurnomo, (2004) "Pengaruh Penerapan Model Problem Based Learning dan Motivasi Belajar terhadap Hasil Pelatihan Fasilitator PNPM Mandiri Perdesaan di Provinsi Jawa Timur"

[4] Depdikbud. (1999). Penelitian tindakan (Action Research). Jakarta : Depdikbud Dirjen Pendidikan Dasar dan Menengah.

[5] Fauziah, R., dkk. (2010). Pembelajaran Saintifik Elektronika Dasar Berorientasi Pembelajaran Berbasis Masalah. Bandung : FPTK UPI. (Online), Vol. IX, No.2, Agustus 2013, (http://jurnal.upi.edu/file/06. Resti Fauziah 165-

[6] 178pdf.pdf, diakses 4 Februari 2014).

Johari.Marjan@pasca.undiksha.ac.id.putu.arnyana@pa sca.undiksha.ac.id.nyoman.setiawan@pasca.undiksha. ac.id
[7] Kementrian Pendidikan dan Kebudayaan. 2013. Implementasi Kurikulum 2013 Konsep Pendekatan Scientific. Jakarta: Departemen Pendidikan dan Kebudayaan.

[8] Mulyono, Y. Dkk. (2012). Pengembangan Perangkat Pembelajaran dengan Pendekatan Scientific Skill Teknologi Fermentasi Berbasis Masalah Lingkungan. Semarang : Universitas Negeri Semarang.(Online), (http://journal.unnes.ac.id/nju/index.php/LIK, diakses 15 Februari 2013).

[9] Sukarno, (1981), Active Learning. Kencana Prenada Media Group:Jakarta.

[10] Soedjito (1983). Menjadi Guru Profesional. Rosda: Bandung.

[11] Sudjana. 1996. Cara Belajar Siswa Aktif dalam Proses Belajar Mengajar. Bandung: Sinar Baru Aljesindo.

[12] Sudjana : (2002) : Statistical Methods. The Lowa State University Press, Ames, Lowa, 1964.

[13] Slameto, 2003. Belajar Dan Faktor-Faktor Yang Mempengaruhi. Jakarta: Rineka Cipta

[14] Sudrajat, A. (2013). Pendekatan Saintifik/IImiah dalam Proses Pembelajaran. (Online), (http://akhmadsudrajat.wordpress.com/2013/07/18/ pendekatan-saintifikilmiah-dalam-prosespembelajaran/, diakses 25 Januari 2014).

[15] Yatin, M., Siti, H., Enni, S., Priyantini, W. 2012. Pengembangan Perangkat Pembelajaran dengan Pendekatan scientific skill teknologi fermentasi berbasis masalah lingkungan. Jurnal Ilmu Kependidikan, 